\title{
Defying the Moulds of Patriarchy: Nomambotwe Khawula of Umzumbe in Natal, 1860 - 1927
}

\section{Bridget Portmann \\ University of KwaZulu-Natal}

The Umzumbe mission station is probably one of the most beautiful and inspiring stations belonging to the American Board Mission. It is situated in the south coast of KwaZulu-Natal and surrounded by rolling hills, endlessly stretching for miles in every direction. The mission station was first conceived in 1861 by Elijah and Addie Robbins and later taken over by Henry and Laura Bridgman in 1869. Under their leadership a church, school and dispensary were all built and opened. The station was also run by Amy Bridgman Cowles, Laura Bridgman's daughter, and her husband George Cowles from 1904. It was this family that have written and passed on the stories of some of the more prominent members of their congregation in Umzumbe. It is in critically evaluating both the author and the subjects of missionary writing that we can learn more about the stereotypes that people faced and their changing nature over the two generations of the three women examined: two of them defying the traditional moulds of patriarchy and the third as the storyteller.

The three actors in this paper are Amy Cowles, Laura Bridgman and Nomambotwe Khawula. Nomambotwe entered the mission station at the age of 10 when she joined the girls' school opened by Laura. She was a nurse to Laura's son, Frederick Bridgman and in her later years she ran a school in Dweshula where her active participation and preaching eventually led to a church being opened and an outstation established ${ }^{1}$

Nomambotwe is positioned in history as a South African born, American educated woman. This is very important to remember when examining her life story as it was told by Amy Bridgman Cowles. Bridgman Cowles comes from a long family history of missionaries working in South Africa. Both her parents were influential in the establishment of a mission station in Umzumbe. Amy Bridgman was born on the Umzumbe mission station and later moved to America, where her parents were from originally, to receive a "proper [western] education". ${ }^{2}$ She then returned to South Africa having married George Cowles. Together they continued the Bridgmans' work as missionaries at Adams, Umzumbe and then retired in California. It was during these years that Amy wrote down the stories of some of the converts that had been taught at the Umzumbe Home School. This school was opened as a place for runaway girls to seek refuge from abusive parents or husbands and avoid unwanted marriages.

I do not want to turn Nomambotwe into a hero by claiming she was the exception, the groundbreaking pioneer of women's rights in the area she lived, however, there is a need to bring to light the female converts and the roles they played in the Zulu mission. There are doubtlessly many women who have recreated life for themselves without the terms of a man and these women are seldom included in the historical record. Black women have been frequently

\footnotetext{
${ }^{1}$ A. Cowles, Nomambotwe (London: The Sheldon Press, 1942).

${ }^{2}$ Laura Bridgman's unpublished manuscript, housed at Campbell Collections, Durban.
} 
overlooked in the quest to save the black man from marginalization. There are a vast number of literary works in which the mission life of a black male student are examined. Black men were allowed to become lawyers, doctors, policemen, politicians and enter other such professional spaces. Although opportunities were limited, they did exist and this has led to a more concise historiography of black male experiences in the mission stations. Women on the other hand are frequently reduced to life in the domestic sphere and their capabilities as intellectuals are vastly ignored. There are very few places women are spoken about and given the same status and positioning as men are given.

Women did not experience the same opportunities as men. Where black men were repressed, black women felt the repression far more. Coming from a patriarchal background where men are naturally considered more powerful and intelligent and women are the ones who are supposed to be at home, looking after the family, ambition is rated lowly. Black women are marginalized due to their race, gender and class ${ }^{3}$ and it is this triple marginalization that makes black women so important to study, not as exceptions but as important players in the making of the history of this country. Women need to be researched in their own right, not as members of a patriarchal system where they are allowed to occasionally enter. Written history can either confront or confirm the social constructions of gender as argued by $\mathrm{Scott}^{4}$. It is the intention of this paper to use the south coast mission station of Umzumbe in KwaZulu-Natal to confront these gender stereotypes, where women have been excluded, to create a social history where women are shown to be the lead actors alongside, and not in relation to, men. They do not need to embody masculine traits that so many women in positions of power have done, for example Margaret Thatcher, or else the stereotypical mother of the nation, the home maker and child-minder. The story of Nomambotwe's life does not fall into either of these categories which is why her story is important and the reason that she should feature in South African historiography.

There are two versions of Nomambotwe's story that were both written by Bridgman Cowles. The one was a transcription of Nomambotwe telling Bridgman Cowles her story while the second was written with the intention of being published in England. The latter version is loaded with propaganda about the benefits of the church and the sinfulness of the "heathen". The former still, however, has its contradictions as the narrator and the transcriber both have their own, possibly conflicting, agendas. However, these contradictions can give us a deeper insight into the story and allow us as historians to deal with the complexities involved in the creation of such a narrative as Nomambotwe's life in a mission school. The availability of both versions of Amy's writing, further allows for the analysis of the purpose of the missionary goal in Umzumbe and the ideas they wanted to portray to the rest of the world. The functioning of the mission station depended greatly on the charity of the churches in America and to a certain extent England. Amy's story would, therefore, be a form of propaganda, possibly for funding, for the African mission project to the western world upon whom they relied. Sending out these brochures and mini-books to their sponsors was one way of showing the people that were supporting them that their money was going to a good cause and they really were helping to make a difference in the lives of the "heathen".

\footnotetext{
${ }^{3}$ C. Walker, "Women and Gender in southern Africa to 1945: An Overview" in Women and Gender in Southern Africa to 1945 (Cape Town: David Phillip Publishers, 1990), 2.

${ }^{4}$ J. Scott, Gender and the Politics of History revised ed. (New York: Columbia University Press, 1999), 9.
} 
Bridgman Cowles wrote numerous stories of different people who were members of the Umzumbe Home School for girls that she sent back to America. However, there are two in particular that stick out and seem to be favourites of hers. One is the story of Nomambotwe and the other is that of Qanda, a hunchback who came to the missionary to seek refuge from the ridicule he experienced with his family. We can only speculate as to why it was these two stories in particular that made such an impact on Bridgman Cowles and why they were considered the stories that should be put into a book and published, perhaps they were the two people that had the most influence in her own life, as her writing seems to suggest. This leads us to have to question the agency of the people involved in these stories as well as the power that the missionaries held in creating the history that would be remembered. Both of these people have been brought to light by a white missionary from America. Had it not been for her then their stories would never have been told, or perhaps they would be remembered by the people in Umzumbe and passed on through an oral tradition with a completely different angle. Therefore not only is Nomambotwe remembered as a form of propaganda, she is only remembered because the missionaries needed to propagate their cause. This cannot detract from the power and interest that the narrative tells us. It just means that it needs to be read critically while the motives behind it are borne in the consciousness of the reader.

The story of Nomambotwe is a powerful one. Although there are many details of her life missing, it is known that she was the daughter of chief Nkumbi Khawula of the Hlongwa and she converted to Christianity at the will of her father. Her father, although he never gave up his polygamous ways, permitted sermons to be given to his people and also attended them himself. This way Bridgman Cowles is able to show that even the chief, the most powerful Zulu person in the community, believed in the Christian mission above traditional values. This would be a strong motivator to people overseas to continue to fund the mission cause as seeing that the people who were the most influential in their community were convinced by the missionaries which implied that their endeavours were successful. Thus a new generation would come into being that believed in Christ and denounced "heathen" ways. The story that Bridgman Cowles writes also emphasises the power that a woman could have if given the correct opportunities, such as a good education and sound Christian morality. Initially Nomambotwe rejected marriage to a chief because he had numerous other wives, in favour of her Christian values. Refusing to marry a chief is no small accomplishment; it is a big thing to deny a chief what he wants. Instead Nomambotwe was content to continue with her work for the missionaries as a nurse to Frederick Bridgman and in return receiving a western education. To anyone reading the book published by Bridgman Cowles ${ }^{5}$ it would seem that once converted, women refused to re-enter their "heathen" lifestyle even given the greatest temptation of marrying a chief. Nomambotwe is fortunate in that her family did not attempt to remove her from the mission as was the case with other girls. Missionaries found it difficult to refuse to return a girl to her mother who would often come to the mission station to demand the girl back. ${ }^{6}$

Nomambotwe's story continues as propaganda material for the missions as she not only refuses to enter a polygamous marriage but she begins to convert others as well. Amy would have probably found it inspiring that not only does Nomambotwe convert her husband to Christianity

\footnotetext{
${ }^{5}$ A. Bridgman, Nomambotwe of Umzumbi: The Woman who Built a School (London: The Sheldon Press, 1942).

${ }^{6}$ H. Hughes, “ 'A Lighthouse for African womanhood': Inanda Seminary, 1869-1945” in Women and Gender in Southern Africa to 1945 ed. C. Walker, (Cape Town: David Phillip, 1990), 213.
} 
but together they raise their children as Christians. Thus showing overseas investors that one convert will lead to many others. Therefore, from the conversion of one woman the mission would potentially result in the creation of an entire Christian family. It then looks like with little effort great things are achieved. Nomambotwe then overcame great hardship with the loss of her children, to illness, and her husband, to the Witwatersrand gold mines.

In the officially published version of Nomambotwe's life, many of the dates and contextual information has been left out. There are no dates in the published version of Nomambotwe's story, no clan name or surname. ${ }^{7}$ She is only known by her first name. In the transcribed version of the story there are details of who Nomambotwe's father was and how he obtained his power. There is also an account of her death and her funeral. None of these are provided in the published account of her life. This could imply that to Bridgman Cowles, Nomambotwe need not be a special case but rather, through the lack of dates and details she becomes a woman from any period with any name. It provides her with a sort of anonymity making her life appear to be a template for other women that the mission has converted.

\section{Nomambotwe Converts}

In some ways, Nomambotwe's life does start out rather unique. She is the eldest daughter of a chief who felt that it would be better for his daughter to become a Christian so that she does not marry a polygamous man. ${ }^{8}$ His reasons for this are unclear and unfortunately there is no record of why he wanted his daughter to avoid polygamy. This is a very interesting stand for a father to take. Jeff Guy argues that in the Zulu tradition women and cattle are what determine the wealth of a $\operatorname{man}^{9}$. The more daughters and cattle he has, the more wives he can afford. He is able to sell his daughters' labour and fertility for lobola (bride price) of cattle, which he could then use to acquire more wives and have more daughters. Although this started as a tradition of goodwill between the husband and the father, it became commoditised by the colonial government when it was codified ${ }^{10}$ Thus, the cycle continues until a man has amassed numerous wives and cattle and is then considered a wealthy man. Thus it is strange that a chief would be willing to send his daughter to a mission station where polygamy is frowned upon.

The opposite usually occurred in the mission station. Girls would run away to them because they knew that the missionaries would try and protect them from their fathers and attempt to help them avoid marrying old men so that their fathers could get the lobola. The case of Nomambotwe seems to be the opposite of this familiar story. She was not happy living with her mother as she would often be beaten which was perhaps due to her mother's jealously of Nomambotwe for being her father's favourite. If any of the women in his life were granted any concessions it would be Nomambotwe. She would always hide behind her father's protection when her mother beat her thereby undermining her mother's influence. After one particularly bad beating that Nomambotwe received from her mother for not chasing monkeys away from the vegetable garden her father sent her to the mission station at the age of ten. ${ }^{11}$ This is presumably

\footnotetext{
${ }^{7}$ A. Bridgman, Nomambotwe of Umzumbi: The Woman who Built a School (London: The Sheldon Press, 1942).

${ }^{8}$ A. Bridgman, Nomambotwe of Umzumbi, 6.

${ }^{9}$ J. Guy, "Gender Oppression in Southern Africa's precapitalist societies" in Women and Gender in Southern Africa to 1945 ed. C. Walker (Cape Town: David Phillip 1990), 36 and 39 to 40.

${ }^{10}$ J. Guy, "Gender Oppression in Southern Africa's precapitalist societies, 36.

11 A. Bridgman, Nomambotwe of Umzumbi, $2-3$.
} 
because she would receive an education and learn about Christianity. It is here that she would intermittently spend the rest of her life. All ties with her mother were severed when she entered the mission station. There is no further correspondence between the two recorded by Bridgman Cowles, and only the occasional visit by her father when he attended services.

Upon her arrival at the mission station Nomambotwe was clothed by the missionaries and welcomed into their congregation. ${ }^{12}$ This was an important part of life at the mission station as it was seen as being fundamental to being a Christian and became entwined with being educated. It defined those that were part of the mission station from those that were not Christian. This is evident in Nomambotwe's claims that she would not look at a man unless he was dressed in Western clothing. She also used clothing as a method of weeding out the men that would lead to a polygamous marriage.

She was approached by a man, Somkeli that was interested in her but he was a chief and therefore would always be a polygamist. She turned him down because she did not love him and knew that she would not be happy living with many of his other wives. ${ }^{13}$ For Bridgman Cowles this would have been an example for people in London that the missionaries where in fact succeeding in their endeavours to promote Christianity. Nomambotwe had seen the life of a chief's wife and had instead chosen to remain a Christian, giving up the power and prestige that came with such a marriage. ${ }^{14}$ Bridgman Cowles quotes Nomambotwe as saying that "...he had a beard which any chief in Natal might covet. Leopard skin aprons, lion-claw necklaces and a bunch of red feathers above his black head-ring, made Somkeli truly gorgeous. He had many wives too, and many cattle." It is clear that Nomambotwe knew what she would be getting into if she were to marry this chief and therefore refused.

\section{Nomambotwe's Marriage}

She continued with her studies at the school in Umzumbe, starting with the school before it had its own building. She spent her nights sleeping on the floor of the Robbins' house. ${ }^{15}$ While she was at school in the mission station she worked for the Bridgmans as a nurse. Surprisingly, she fell in love with another worker at the mission station who was not a Christian, Muhle. ${ }^{16}$ When he proposed to her she felt torn between love and her Christian morals and eventually agreed only to marry him on the condition that he converts to Christianity. He, however, could not afford to marry her without the support of his father in raising the lobola of 15 cows. For this reason he asked her to marry him in a traditional manner and then they would both convert to Christianity when they had given the lobola to her father, the chief. Still undecided she turned to Gugu, an old woman who had been with the mission since it started. Gugu urged her to accept Muhle as he was a good man and so she agreed to his terms. Nomambotwe left the mission station and they were married in the traditional Zulu manner. Her father was upset that his favourite daughter had rejected Christianity but he accepted their marriage and took the lobola from Muhle's father for Nomambotwe's marriage.

\footnotetext{
${ }^{12}$ A. Bridgman, Nomambotwe of Umzumbi 4.

${ }^{13}$ A. Bridgman, Nomambotwe of Umzumbi, 5.

${ }^{14}$ See Zulu Woman for another take on this, where Christina Sibiya leaves her Christian upbringing behind and marries the Zulu king.

${ }^{15}$ A. Bridgman, Nomambotwe of Umzumbi, 5 to 8 . The Robbins family lived at Umzumbe with the Bridgman family until illness forced them to leave.

${ }^{16}$ His surname is, unfortunately unknown.
} 
On the day of the wedding she wore a skirt of cow hide and deer skin with brass buttons tied on the back which hung over her shoulder covering down to the skirt. Her hair was woven with grass and rubbed with red clay and grease. On top of her head she had long black feathers and she held a white shield. ${ }^{17}$ To celebrate her wedding to Muhle she made beer and two oxen were slaughtered. There were also the dances of the bride's party and then those of the groom's party. After the celebrations she went into the hut to begin her duties as a wife.

Nomambotwe therefore reverted to a non-Christian lifestyle for a number of years in order to pacify her husband's father. Her father died before the marriage ceremony with the belief that his daughter had married a polygamist and sending her to the mission station had in fact been useless. $^{18}$ This must have indeed been a trying time for Nomambotwe. She had lost her immediate family when she was 10 , her father had died and she was living a life she did not want to, all for the procurement of the lobola her husband had to pay in order to ensure he possessed her. Being a black woman in Natal, Nomambotwe was subject to customary law which at that time stated that all marriages had to be registered and a marriage fee of $£ 5$ had to be paid to the colony, it also limited the number of cattle for lobola. Therefore, lobola became compulsory and ensured that fathers were still relatively in control with regards to their daughters' marriages. ${ }^{19}$ The laws about lobola were supposed to give more freedom to women in their choice of husbands. However, what the law did manage was ensure that black women remained minors in the eyes of the law and they were unable in inherit immovable property when their husband's died, instead they were under the control of their sons or husband's brother. ${ }^{20}$ This ensured that black Christian women were always under the power of a man. Although the missionaries did not condone the practice of lobola they were powerless to prevent it.

\section{The Christian Calling}

After a year of marriage Nomambotwe began to long for Umzumbe and had been pressurising her new husband to move back into the mission station and become a convert but he had been continually resisting. It was roughly two years later that she was able to convince him that it was time for her to return to the mission station and for him to convert to Christianity like he had promised. Therefore, one night they left their homestead and returned to the mission station. They went to Gugu's house where they stayed until morning when they were able to present themselves to the missionary in charge who, at that time, would have been Henry Bridgman.

Upon their return they were given land where they could build their own house and raise their family. Bridgman Cowles does not mention it but it is likely that they would have had to be married again with Christian vows after they were both baptised. They had seven children together, however five of them died. There are no recorded ages of any of the children or any other mention of the feelings Nomambotwe felt at their loss as Bridgman Cowles writes in a very factual and distant manner. It is unknown if the children died at birth or of illness at a later stage or due to poverty and lack of food. There was no proper medical care in the mission station at

\footnotetext{
${ }^{17}$ A. Bridgman, Nomambotwe of Umzumbi,7.

${ }^{18}$ A. Bridgman, Nomambotwe of Umzumbi, 6.

${ }^{19}$ S. Meintjes, "Family and gender in the Christian community at Edendale, Natak, in colonial times" in Women and Gender in Southern Africa to 1945, 141.

${ }^{20}$ S. Meintjes, "Family and gender in the Christian community at Edendale, Natal, in colonial times" in Women and Gender in Southern Africa to 1945, 142.
} 
this stage. Medical treatment would have had to be sought at Adams or Durban, both of which were great distances away from Umzumbe as the first dispensary was only established around 1905 by an ex-McCords hospital nurse Loretto Gumbi ${ }^{21}$ with the help of the Durban Health Department.

\section{Abandonment and Survival}

It appears that Muhle and Nomambotwe were unable to support themselves on the mission land and Muhle had to move to Johannesburg to work on the gold mines as a migrant labourer. As is so typical with the South African situation of migrant labour, Muhle probably went away to try and earn money for his family to pay the colonial taxes imposed on all African men. In particular the hut tax demanded that African societies pay the tax, regardless of their yield that year. ${ }^{22}$ The end of the 1800s saw locust swarms, drought and in 1897 a severe rinderpest epidemic that cost people greatly and forced more people onto the gold mines because of a need to pay the 14 shilling hut tax. ${ }^{23}$ As women were considered to be the homemakers, the colonial government felt that women did not belong in the cities and women that lived in the cities were labeled as immoral deviants. ${ }^{24}$ Women were instead encouraged to stay in rural areas to continue farming and looking after children. Both the colonial government and the chiefs had reasons for wanting women to remain in rural areas and not move into the cities with their husbands. Customary law was interpreted by husbands and chiefs in a patriarchal manner that attempted to relegate women to the domestic sphere as chiefs wanted to keep the women in rural areas as they did the bulk of subsistence farming. The migrant labour system was also designed so as to keep wages as low as possible by not encouraging women to join their husbands at the mines and the low wages ensured that return home was financially unwise because a man would be left with little money.

Deep-level gold mining, which is necessary in South Africa, was labour intensive and demanded a large amount of work for small amounts of gold as it was low-grade ore being mined. Mining companies therefore had to keep their costs to a minimum. One of their biggest costs was labour and companies tried to keep labour costs as low as possible. Migrant labourers were never paid enough to properly support their families back home. In order to keep their costs down mine owners paid a migrant labourer enough to support himself only, without having to concern themselves with the labourers' families. This also meant that labourers would have to stay on the mines far longer in order to save any money. Life with their wives would become strained as they were separated for such long periods ${ }^{25}$. When men returned from the mines their wives were often not willing to obey them any more as they were no longer dependant on them because they had to subsist without a male head. The tensions would cause men to build a new life for themselves on the mines and in some cases fall in love and marry another woman. Many women were therefore left at home to look after the families and their husbands never returned and sent none of that promised money.

${ }^{21}$ C. Cruikshanks, The Annals of Umzumbe 1860-1965 written for the Women's Institute (1965), 6.

${ }^{22}$ C. Walker "Gender and the migrant labour system" in Women and Gender in Southern Africa to 1945 (Cape Town: David Phillip 1990), 174.

${ }^{23}$ C. Walker "Gender and the migrant labour system" in Women and Gender in Southern Africa to 1945 (Cape Town: David Phillip 1990), 175.

${ }^{24}$ C. Walker "Gender and the migrant labour system" in Women and Gender in Southern Africa to 1945 (Cape Town: David Phillip 1990), 179.

${ }^{25}$ C. Walker "Gender and the migrant labour system" in Women and Gender in Southern Africa to 1945 (Cape Town: David Phillip 1990), 193. 
Nomambotwe was one of the many women who never heard from her husband again and had to begin to support her two children, one of whom was a baby, by herself. It became possible for women to have more freedom due to the migrant labour system as they had to support themselves in whichever manner was available to them. ${ }^{26}$ Women started businesses such as brewing beer or domestic work in order to survive. However, black women were still on the lowest rung of society suffering the triple oppression as black women, the poorest people in society, and unable to own private property as they were considered perpetual minors in the eyes of the colonial government. Colonial authorities who had arrived in Africa from a strictly patriarchal society attempted to understand Zulu customs through a particularly structured lens and codify their laws into what became customary law. Through interactions with the chiefs, the government asked about traditions in order to form definite laws to govern black people. The chiefs saw the advantage for themselves and other men in improving their situations if they were to marginalise women in order to cement their power. ${ }^{27}$ Women were the main farmers in a Zulu community and chiefs needed women to stay at home to ensure that there was food for the men that remained. Therefore, the chiefs used the colonial government's desire to have a fixed set of customary laws in order to restrict women. Customs then become fixed, whereas before they were far more flexible, and thus were now to the detriment of women. Rural areas experienced the contradiction of "dissolution" and "conservation" in that colonial government tried to keep customary law active while at the same time forcing men to urbanise. ${ }^{28}$ The same laws applied to women whether they were Christian or not. Women just moved from one form of subordination to another one.

Thus Nomambotwe would have had to take on the full responsibility of looking after her children without the aid of a husband. All agricultural work would have fallen into her hands as well as having to look after her two children. Despite all this added work she would not be allowed her to own any of her own land nor make any legal decisions. The laws ensured that she would have to be indebted to someone in order to feed herself and her children. In order to support her children she went back to the mission and began to work for the missionaries. She worked in Umzumbe Home as a teacher and helper. By this stage the school had its own building and had a substantial amount of children. She worked there as a teacher for 4 years until a teacher was requested for a nearby outstation in Dweshula.

\section{Chief Mabojane and Dweshula}

Dweshula was the name of a clan almost 25 kilometres from Umzumbe. It was run by a nonChristian chief, who heard about Christianity and it peaked his interest in the subject. Chief Mabojane came occasionally to the Umzumbe Church after having heard converts preaching in his community. The converts were members of the Umzumbe church who felt it important to spread the word of God to people who could not attend church. These converts traveled the $25 \mathrm{~km}$ to Dweshula on foot in order to sermonise there. After a while he approached the Bridgmans and requested a teacher for his children. Chief Mabojane, at this time was not a Christian. It is an interesting choice that he rejected the missionaries preaching, yet he still

\footnotetext{
${ }^{26}$ C. Walker "Gender and the migrant labour system" in Women and Gender in Southern Africa to 1945 (Cape Town: David Phillip 1990), 192.

${ }^{27}$ C. Coquery-Vidrovich African Women: A Modern History (Boulder, Columbia: Westview, 1997$), 65$.

${ }^{28}$ C. Murray, Families Divided: The Impact of Migrant Labour in Lesotho (Johannesburg: Ravan Press, 1981).
} 
desired that his children were properly schooled in western education. He, himself, never learnt to read or write. It is notable that two major male figures were interested in the modernisation of their children but themselves turned away from the preaching of the church. Nomambotwe's father, also a chief, ensured that his daughter became a Christian in order to avoid a polygamous marriage to a non-Christian and yet he would have been a prime example of a polygamist. Mabojane was not a Christian and yet he desired that his children be schooled by the missionaries, knowing that they would be taught the bible and it would be the primary textbook.

It was decided by Laura and Henry Bridgman, George Cowles and Bridgman Cowles herself that Nomambotwe should be the one that taught the chief's children. She was perhaps the easiest person to send as her children would be at a stage of being ready to be taught themselves and she had no husband to keep her tied down. Bridgman Cowles describes her "... as being eminently the best person to start that first school in a heathen (sic) community" ${ }^{29}$ She started school at Umzumbe when it first opened and the aspirations of the Mt. Holyoke Seminary were still fresh in the mind of Laura, who would have been the most influential teacher in her life. For Nomambotwe schooling had been her way out, her chance of survival. She had spent the hardest times of her adult life supporting herself and her children without a husband, using the schooling she had learnt in her early years at Umzumbe to become a teacher. She was the first missionary to officially start working in Dweshula. Nomambotwe started teaching in a hut from which she cut two windows to allow light inside. She achieved quite a name for herself in Dweshula and Amy recalls that

“...one can hardly ask for a more thrilling story of Christian heroism than that of Nomambotwe's first term of service at Dweshula's. A teacher-evangelist she was! Out of school hours, she was preaching everywhere, tending to the sick, burying the dead, helping old Dweshula to "come over to the top", at last in his decision to be a Christian, and that after thirty years of trying, on his part." 30

Nomambotwe was clearly romanticised by the missionaries she served. Her life became a portrait for the perfect convert and this is evident in the idealised woman who is portrayed in the texts by Bridgman Cowles.

\section{Ingwe yabantwana: Nomambotwe has the school in stitches}

Nomambotwe, however, is not as perfect as she is portrayed by Bridgman Cowles. At first she could get only boys to come and learn because mothers did not want to allow the girls to leave as they had to look after their babies. ${ }^{31}$ To compromise, she then told them to bring the babies to class as well. When George Cowles came to check on the school there were fourteen children altogether - seven girls with babies on their backs and a few younger brothers were in attendance sitting on the floor working on slates with pencils.

The babies caused the biggest disturbance in the classroom and in order to keep the babies quiet during her lessons Nomambotwe "applied tiny stitches to their legs". ${ }^{32}$ After a very short while the babies realised that if they cried for unnecessary reasons they would be cut by Nomambotwe's needle. In this manner she was able to quiet the babies and won the nickname

\footnotetext{
${ }^{29}$ A. Bridgman, Qanda at Dweshula, unpublished manuscript at PMB archives AMB A608 A/4/62, 7.

${ }^{30}$ A. Bridgman, Qanda at Dweshula, 8.

31 A. Bridgman, Nomambotwe of Umzumbi, 10.

${ }^{32}$ A. Bridgman, Qanda at Dweshula, 7.
} 
"Ingwe ya bantwana" meaning "Tiger of the Babies". Later the mothers actually thanked her and renamed her "wa tulisa izwe" which means "hushed up the country". This part of the story has been omitted from the published version of Nomambotwe's life, in the published version she was credited for having "trained the babies" and there was no further expansion on this. ${ }^{33}$ It would seem that Nomambotwe was proud of her work in silencing the children by cutting their legs if they were too loud but, naturally, Bridgman Cowles considered this too brutal to include in her published version. I suspect that it would not be well received if she wrote about such treatment of babies in a missionary school setting.

\section{A hero like a man}

The school in Dweshula started growing as it had the support of the chief, and Nomambotwe was legendary for her ability to quiet the children. The school grew from fourteen to forty children learners over a short period of time. The hut they had been using became completely unsuitable and Nomambotwe realised it would be necessary to build a proper school building. She could not get anyone in the community to help her build the school, which shows that perhaps she had the chief's support, which was the reason other members of the community sent their children to school, but was not supported by the entire community. At this stage the chief was getting very old and this could perhaps explain his lack of participation in the building of the school. Despite the lack of support, Nomambotwe set out to build the school herself with the children. They would spend two hours working on building the school for the most part of the week. Some children were assigned to the cutting of grass for the thatch and others had to walk to the forest 2 miles away and cut the trees down for the wooden poles.

That year much of the cattle had been killed by tick bite fever and there were no cows to spare to pull the logs up the hill to the location of the school. In order to solve this problem Nomambotwe tied rope onto the children's waists and the other end to the logs. They pulled the logs up the hill while she pushed from behind. In this way they were able to bring the logs from two miles away to the new school. They managed to pull all the logs up the hill in a matter of two hours. She used the logs to build the frame of the school building and then wove between using basket work. ${ }^{34}$ All this Nomambotwe accomplished with the help of the school children while the men looked on in amusement at this woman doing man's work and building a school. There was a general feeling that since this was man's work, a woman could not successfully complete the project and hence no one offered to help her. Finally, the main part of the building was complete and Nomambotwe was finishing off the weaving on the roof when at last help arrived and one of the chief's sons chased her off and completed the roof for her. ${ }^{35}$

The basic structure of the building was completed and the last thing left to do was plaster the walls with mud. This Nomambotwe and the children did; thereafter, they polished the floors and whitewashed the walls with clay from nearby. This must have been an amazing accomplishment; a woman had set out to a small village, away from her home where she had spent her entire life, to teach the children of the chief the same things she had learned from the Umzumbe Home all those years ago. Her school had grown and become successful and now, without support and

\footnotetext{
${ }^{33}$ A. Bridgman, Nomambotwe of Umzumbi, 10.

${ }^{34}$ A. Bridgman, Nomambotwe of Umzumbi, 11.

${ }^{35}$ A. Bridgman, Nomambotwe of Umzumbi, 12.
} 
encouragement from the people she was teaching, she had managed to build a school building big enough to hold forty children.

In order to celebrate the opening of the school Nomambotwe called for all the children to bring something to eat and they would hold a big opening ceremony. She herself made jam sandwiches and provided tea while Mabojane offered a pig for slaughter. Parents sent chickens, beans and other food. This is perhaps an indication that they too were impressed by the strength and stamina that Nomambotwe showed in the building of the school. They did not help her in the construction of the school yet they were fully supportive of her after it had been built. It seems that Nomambotwe managed to obtain the respect of all the people in the community that she was working. Hundreds of people attended, although this could perhaps be an exaggeration on Bridgman Cowles's part.

Most people who attended church services were not Christians. The last time she was the important figure around non-Christians was her marriage and this is contrasted to her current position as teacher and preacher of the gospel. This was truly a proud moment for the missionaries in Umzumbe. This woman was a non-Christian, became a Christian then went back to her non-Christian ways and returned to being a Christian and here she is preaching to the same people she used to be able to relate to. This occasion earned her a new name Qhawe, adhlangandoda - "a hero like a man". ${ }^{36}$ This seems to be a turning point for Nomambotwe, she has become accepted into the community and people are far more willing to listen to her and respect her. At the same time, however, she still had many enemies as she preached against the drinking of beer and women that converted to Christianity did not want to make the beer for their husbands. This annoyed them and they blamed Nomambotwe. This was to get her into trouble later on.

\section{The Chief Converts}

Every Sunday she gave a sermon that was attended by people dressed in blankets or skins. One day, suddenly, Chief Mabojane stood up and announced that he chose the Lord and gave up all his wives but one and stopped drinking spirits and beer. From this sprung up plenty of other conversions as people fell in line to follow their chief. For example, women gave up their potions and charms after their conversion. The community began to show how they no longer believed in "witchcraft" by renouncing their old beliefs. One woman admitted that she thought her motherin-law was trying to poison her children through "witchcraft"; while another had prepared love medicine to give to her husband so she would be loved more than the other wives. ${ }^{37}$

The chief then had a church built for all the new Christian converts with the help of George Cowles who promised to pay for the brick walls and windows if the people of Dweshula would either pay for an iron roof or thatch a roof. Unfortunately before the church was completed the chief died, and on his death bed his eldest son promised to convert to Christianity. This all happened after Nomambotwe had left Dweshula and returned to Umzumbe in her old age. In the published story of Nomambotwe it is implied that the church was built while she was still there

\footnotetext{
${ }^{36}$ Spelling corrected from Xawe to Qhawe meaning "hero". Original text found in A. Bridgman, Nomambotwe of Umzumbi, 13.

${ }^{37}$ A. Bridgman, Nomambotwe of Umzumbi, 13.
} 
as a teacher. However, the church was only opened in 1924 and Nomambotwe left Dweshula before $1916^{38}$ after having requested a more qualified teacher be sent to the school there. ${ }^{39}$

\section{Nomambotwe is Arrested}

In 1910 Halley's Comet appeared in the sky and people associated the comet with a visit from God. In the published version of Nomambotwe's life, the story is told that many people converted to Christianity as they feared that God would punish them otherwise. Women stopped making beer because missionaries had been preaching that alcohol was bad, girls stopped going to the dances and traditional weddings became poorly attended. The Chief Mabojane was not happy with the situation and used his influence to have Nomambotwe arrested for frightening the people. In protest to Nomambotwe and Christianity it was reported to the government that she was using the sighting of the comet as an excuse to preach that the end of the world was coming and people needed to convert before God arrived. She was arrested for disturbing the peace because she was allegedly causing panic in Dweshula. There was great opposition to his decision and people began to raise money to bail her out. Eventually the American Board had to send a missionary to get her released. She was released shortly after she was arrested. ${ }^{40}$

Yet, the story is slightly more nuanced then this. After the chief had converted to Christianity many of the people followed him in his decision. The women who converted did stop making beer and some of the men felt that their customs were being lost because of Nomambotwe and her preaching. As a young married woman Nomambotwe joined Laura's group pledging neither to drink nor to brew beer. She and her husband were among the first couples to agree not to drink beer so as to set an example for other converts. Drinking was seriously frowned upon by the missionaries in Umzumbe and this practice was continued by Nomambotwe in Dweshula. Thus, the women felt that Nomambotwe was stealing their livelihood by encouraging people to stop drinking. In order to discredit her, the community had her arrested for disturbing the peace.

\section{Nomambotwe at McCords Hospital}

The school continued to grow and when Nomambotwe became too old to run the school and felt that she was no longer sufficiently qualified to teach the desired level, two qualified teachers were sent to teach the eighty children that were in daily attendance. Nomambotwe returned to Umzumbe where she spent her final days. She suffered greatly from rheumatism which eventually had her confined to a bed. When she arrived at Umzumbe she was being cared for by her adopted granddaughter Busisiwe. ${ }^{41}$ From her bed she would preach and teach, calling people that were "backsliding" from their Christian values to her so she could pray for them. ${ }^{42}$ Her nephew Isaac Khawula (who was a brother of chief Dingezweni) would fetch her in a wheelbarrow to take her to church on Sundays where she was carried to her seat in front of the pulpit. From there she would sing or pray the loudest. Eventually she needed proper medical care and could not be helped any longer by Busisiwe and the missionaries. Dr. Taylor from McCord Hospital fetched her in his car and she was taken to the hospital after she gave Busisiwe into Amy and George Cowles's care. McCord hospital was started by Dr. James McCord when he

\footnotetext{
${ }^{38}$ The date she left was sometime between 1910 when Nomambotwe was imprisoned and 1916 when George Cowles was put in charge of the Umzumbe mission district.

${ }^{39}$ A. Bridgman, Qanda at Dweshula, 7.

40 This second account is taken from Amy Bridgman's unpublished writing on Qanda, the preacher at Dweshula.

${ }^{41}$ Busisiwe became a qualified teacher under the care of Amy and George Cowles.

${ }^{42}$ A. Bridgman, Nomambotwe: the sequel. Unpublished version housed at PMB archive AMB papers A608 A/4/62.
} 
found there was a need for a proper medical facility for black people. The funds used were entirely self-generated by McCord himself. The hospital also had close ties to Christianity and Nomambotwe would have felt quite comfortable while there.

Her time in the hospital was spent praying for those that were sick and dying. She was carried to every meeting that was held and helped people wherever she could. She died in July 1927 at McCord Hospital. She was buried in Adams Mission Station alongside Elijah and Addie Robbins, the founders of Umzumbe, who were next to Laura and Henry Bridgman - the missionaries with whom Nomambotwe had so long shared her life and thoughts. Soon after she was buried there the ashes of Frederick Bridgman, the boy she had once been a nurse to, were scattered by his parents and fittingly on Nomambotwe's grave.

\section{Conclusion}

Bridgman Cowles's final mention of Nomambotwe clearly shows the fondness that the missionaries held for her:

These four missionaries [Laura, Henry, Addie and Elijah] were the pioneers of Umzumbi Mission Station. It was into their hands that Chief Nkumbi gave his little Inkosazana. It was because of the faithful guidance and instruction of those early missionaries that this little spark of love to God was kindled in the heart of the child Nomambotwe, the little spark that never died out, the little spark that became the still small voice of conscience in the midst of temptation and sin; the little spark that later gave courage to condemn and shout against wrong-doing; the little spark that helped Nomambotwe to bear her sorrows and bereavements; the little spark that grew so big that it gave strength to Nomambotwe to endure all things and to hope all things (Emphasis original). ${ }^{43}$

Nomambotwe had become part of the Bridgman family during her years serving them, first as a nurse and then as a teacher. The above extract, although very lavish and extravagant shows the closeness that Bridgman Cowles felt towards Nomambotwe. She had entered their lives at a very young age and had known her from the start. She also had a close relationship to Frederick and would have spent a large amount of time in the house with the family. Nomambotwe's final resting place was so fittingly among the people that had influenced her and helped her become more then a chief's wife. She became a teacher and an inspiration to the people she taught and to the people that had once taught her. Bridgman Cowles's words show that Nomambotwe became as important to the mission station as the original American missionaries who arrived there nearly 70 years before her death. She had grown up with the mission station and in turn it had grown with her.

\footnotetext{
${ }^{43}$ A. Bridgman, Nomambotwe. Unpublished version.
} 
